Mediterranean Journal of Humanities mjh.akdeniz.edu.tr IV/2, 2014, 1-17

\title{
Modellemeye Dayalı Fen Öğretiminin İlköğretim Öğrencilerinin Anlama, Hatırda Tutma, Yaratıcılık Düzeyleri ile Zihinsel Modelleri Üzerine Etkisi
}

\author{
The Effects of Modelling Based Science and Technology Teaching on \\ Understanding, Memorization, Creativity and the Mental Models of Primary \\ School Students
}

\begin{abstract}
Ahmet ARSLAN* Mustafa DOĞRU**

Öz: Bu araştırmanın amacı, Fen ve Teknoloji dersi "Madde ve Isl" ünitesinin Modellemeye Dayalı Öğretim yöntemi (MDÖY) ile işlenmesinin; İlköğretim altıncı sınıf öğrencilerinde anlama, yaratıcılık, hatırda tutma düzeyleri ve zihinsel modelleri üzerine etkisini incelemektir. Araştırmada karma yaklaşım benimsenmiştir. Karma yaklaşımın nicel boyutunda ön-test/son-test kontrol gruplu yarı deneysel desen, nitel boyutunda ise olgubilim deseni kullanılmıştır. Deney grubuna modellemeye dayalı öğretim yönteminin Halloun'un beş aşamalı modelleme döngüsü (HBAMD), kontrol grubuna ise yapılandırmacı yaklaşımın 5E modeli uygulanmıştır. Araştırmada elde edilen nicel verilerin analizi tek faktörlü kovaryans analizi (ANCOVA) kullanılarak, nitel veriler ise olgu bilim desenine uygun olarak değerlendirilmiştir. Araştırma bulgularında, anlama ve hatırda tutma düzeyi açısından gruplar arasında bir fark olmadığı; yaratıcılık düzeyleri açısından ise deney grubu öğrencilerinin daha yüksek yaratıcılı̆̆a sahip olduğu bulunmuştur. Araştırmanın nitel boyutunda ise modellemeye dayalı öğretim yönteminin öğrencilerin zihinsel modellerini olumlu yönde etkilediği gözlenmiştir.
\end{abstract}

Anahtar sözcükler: Modelleme, anlama, hatırlama, yaratıcılık, zihinsel model

Abstract: The purpose of this research was to investigate the effects of modelling based teaching methodology, applied to the "Material and Heat" unit of the Science and Technology course, on understanding, memorization levels, creativity and the mental models of sixth grade primary school students. The mixed approach was applied in this research. For the quantitative component of the approach, the group controlled pre-test/post-test quasi-experimental set up, and for the qualitative component, the phenomenal set up, were employed. On the test group, Halloun's five step modelling cycle of modelling based teaching methodology and on the control group, the $5 \mathrm{E}$ model of the constructive approach were applied. Evaluations of the collected quantitative data were conducted employing single-factor covariance analyses (ANCOVA) and the qualitative data were descriptively evaluated according to the phenomenal set up. The results indicate that there is no difference between the test group and the control group in respect to understanding and memorization, but the creativity levels of the test group students were found to be higher. The qualitative dimension of the results of this research indicates modelling based teaching methodology positively affects the mental models of students.

Keywords: Modelling, understanding, memorization, creativity, mental model

\footnotetext{
*Fen ve Teknoloji Öğretmeni, Milli Eğitim Bakanlığı, İstanbul, ahmetarslan5761@gmail.com

** Yrd. Doç. Dr., Akdeniz Üniversitesi, Eğitim Fakültesi, İlköğretim Bölümü, Antalya, mustafadogru@akdeniz.edu.tr
} 


\section{Giriş}

Öğrenme ortamında kullanılan modeller, öğrencilerin ilk defa gördükleri teorilerdeki önemli noktaları daha kolay anlamalarını, öğrendikleri yeni konularla ilgili test edilebilir hipotez kurmalarını, eleştirel analiz yapmalarını, yaptıkları gözlem ve araştırmalarda neyin önemli olup olmadığına karar vermelerini sağlamıştır (Durmuş, \& Kocakülah, 2006, 301).

Güneş, Gülçiçek ve Bağcı (2004, 48), modellemeyi bilimsel düşünme ve çalışmaların oluşturduğu bir sürecin işlemleri olarak tanımlarken, modelleri bu işlemler sonucunda ortaya çıkan ürünler olarak tanımlamaktadır. Okullarda modelleme ile yapılmak istenen öğrencilerin sahip oldukları ön bilgilerinden, zihinsel modellerinden ve modellemenin süreçlerinden yararlanarak bu öğrencilerin sahip oldukları zihinsel modelleri mevcut bilimsel modellere uygun hale getirmektir (Harrison, \& Treagust, 1998, 421).

MDÖY, öğrencilerin daha sağlam zihinsel modeller oluşturmasını sağlamıştır (Clement, \& Steinberg, 2002, 390). Bilişsel faaliyetler sonucunda öğrencilerin zihinlerinde oluşturdukları temsiller zihinsel modellerdir (Vosniadou, 1994, 48). Bireyin deneyimlerine dayalı olarak hedef sisteme ait modellemiş olduğu zihinsel modeller, davranış, sözlü veya yazılı ifadeler ve diğer betimleme araçları ile açığa vurulur (Gobert, \& Buckley, 2000, 892).

Modellemeler, öğrencilerin kavramsal bağ kurabilme düzeylerini arttırarak anlamlı öğrenme gerçekleştirmelerini ve daha iyi problem çözebilmelerini sağlamıştır (Frederiksen, White, \& Gutwill, 1998, 806). MDÖY, öğrencilerin modellerle temsil ettikleri gerçekler arasında bağ kurabilmelerini kolaylaştırmıştır (Barab, Hay, Barnnet, \& Keating, 2000, 719). Bloom'un güncellenmiş taksonomisinde anlama; öğrencinin kendisine verilen sözlü, yazılı ya da grafik biçimindeki eğitim iletilerinden anlam çıkarma olarak tanımlanır. Güncellenmiş taksonomide bilgi birikimi boyutunun kavramsal alt boyutunu oluşturan öğelerden biri model bilgisi iken, bilimsel süreç boyutunun anlama alt boyutunu oluşturan öğelerden biri de model oluşturmadır (Anderson, et alii, 2010, 66, 98-99).

Akın ve Pesen $(2010,86)$ matematik alanında yaptıklanı çalışmada deney grubuna özdeşliklerin elde edilmesinde tam küp modelini uygulamışlar ve model kullanılan deney grubunda modelin hatırda tutuculuk düzeyini olumlu yönde etkilediği sonucuna varmışlardır. Öğrenilen bir materyalin uzun süreli bellekten geri getirilmesi süreci hatırlama olarak tanımlanabilir (Anderson, et alii, 2010, 85).

Doğrudan gözlenemeyen varlıklarla ilgili teori ve modeller incelendiğinde bilimin müthiş bir hayal gücü ve yaratıcılık içerdiği görülebilir (Köseoğlu, 2010, 28). Bir bireyde yaratıcı düşüncenin geliştirilebilmesi için sentez, analitik ve pratik yeteneklerinin bulunması ve bu üç yetenek arasında bir dengenin oluşturulması gerekir (Saban, 2009, 121-122).

\section{Amaç}

$\mathrm{Bu}$ araştırmanın amacı, İlköğretim 6. sınıf Fen ve Teknoloji dersi "Madde ve Isı" ünitesinde Modellemeye Dayalı Fen Öğretimi’ne (MDFÖ) göre düzenlenerek yürütülmüş bir öğretim süreciyle, öğrencilerin anlama, hatırda tutma, yaratıcılık düzeyleri arasında anlamlı bir ilişki olup olmadığını ve MDFÖ’nin öğrencilerin "Madde ve Isı" ünitesiyle ilgili zihinsel modellerini nasıl etkilediğin incelemektir.

$\mathrm{Bu}$ nedenle araştırmanın alt problemleri şu şekildedir:

1. Öğrencilerin MDFÖ öncesindeki Anlama Düzeyi Testi (ADT) puanları sabit tutulduğunda, MDFÖ ile ADT puanları arasında anlamlı bir ilişki var mıdır?

2. Öğrencilerin MDFÖ öncesindeki ön yaratıcılık düzeyleri puanı sabit tutulduğunda, 
MDFÖ ile son yaratıcılık düzeyleri puanı arasında anlamlı bir ilişki var mıdır?

3. MDFÖ sonunda yapılan ADT puanları sabit tutulduğunda, MDFÖ ile bir ay sonra gerçekleştirilen ADT puanları arasında anlamlı bir ilişki var mıdır?

4. İlköğretim 6. sınıf Fen ve Teknoloji dersinde MDFÖ’nün uygulandığı deney grubu öğrencilerinin çalışma öncesindeki zihinsel modelleri ile çalışma sonrasındaki zihinsel modelleri arasında ne gibi farklılıklar vardır?

\section{Yöntem}

$\mathrm{Bu}$ araştırmada karma yaklaşım kullanılmıştır. Karma yaklaşım pozitivizmi ve fenomolojiyi içeren bir yaklaşım türüdür (Altunışık, et alii., 2010, 62-64).

Karma yaklaşımın nicel boyutunda, deneysel araştırma türlerinden, çok denekli yarı deneysel desenin, eşleştirilmiş desen formatında öntest-sontest eşleştirilmiş kontrol gruplu desen kullanılmıştır (Büyüköztürk, et alii,, 2012, 198-210). Çalışmada yansız atama yolu ile, birbirine denk olan iki şubeden biri deney grubu, diğeri de kontrol grubu olarak atanmıştır. Gruplara deney öncesi ve sonrası ölçümler yapılmıştır. Çalışmanın nicel boyutu Tablo 1'de özetlenmiştir.

Tablo 1. Öntest-Sontest Eşleştirilmiş Kontrol Gruplı Desen

\begin{tabular}{|l|l|l|l|}
\hline Grup & Öntest & İşlem & Sontest \\
\hline 6B (Deney) & $\begin{array}{l}\text { Anlama Düzeyi Testi, } \\
\text { Torrance Yaratıc1lk Ön Test }\end{array}$ & $\begin{array}{l}\text { Modellemeye Dayalı } \\
\text { Fen Öğretimi }\end{array}$ & $\begin{array}{l}\text { Anlama Düzeyi } \\
\text { Testi, Torrance } \\
\text { Yaratıc1ık Son Testi }\end{array}$ \\
\hline 6A (Kontrol) & $\begin{array}{l}\text { Anlama Düzeyi Testi, } \\
\text { Torrance Yaratıc1lk Ön Testi }\end{array}$ & $\begin{array}{l}\text { 2005-2006'da Kabul } \\
\text { Edilen Fen ve Teknoloji } \\
\text { Öğretim Programı }\end{array}$ & $\begin{array}{l}\text { Anlama Düzeyi } \\
\text { Testi, Torrance } \\
\text { Yaratıcılı Son Testi }\end{array}$ \\
\hline
\end{tabular}

Karma yaklaşımın nitel boyutunda, öğrencilerin zihinsel modellerinin gelişimini belirlemede olgu bilim deseni kullanılmıştır (Yıldırım, \& Şimşek, 2011, 72-80).

\section{Çalışma Grubu}

Çalışma; İstanbul ili, Beyoğlu ilçesine ait bir İlköğretim Okulu'nda gerçekleştirilmiştir. Okulda bulunan iki 6. sınıf şubesinde öğrenim gören toplam 58 öğrenci araştırma kapsamına alınmıştır. Deney ve kontrol gruplarının, çalışmanın başlamasından önce akademik başarı açısından denkliklerini saptamak amaciyla kanıt toplama yoluna gidilmiştir. Bu nedenle deney ve kotrol grubunu oluşturan öğrencilerin bir önceki döneme ait karne notları esas alınarak, ortalamalar arası fark t-testi kullanılarak tespit edilmiştir. Analiz sonuçları Tablo 2'de sunulmuştur.

Tablo 2. Deney ve Kontrol Grubu Öğrencilerinin Karne Notu Ortalamaları Bağımsız Gruplar T-Testi

\begin{tabular}{|l|l|l|l|l|l|l|}
\hline Cinsiyet & $\mathbf{N}$ & $\overline{\boldsymbol{X}}$ & $\mathbf{S}$ & $\mathbf{s d}$ & $\mathbf{t}$ & $\mathbf{P}$ \\
\hline Deney & 31 & 69.21 & 13.97 & 56 & 1.68 & .098 \\
\hline Kontrol & 27 & 74.61 & 9.67 & & & \\
${ }^{*} \mathrm{P}<.05$ & & & & & \\
\hline
\end{tabular}

Tablo 2'de görüleceği gibi deney grubundaki öğrenciler ile kontrol grubundaki öğrencilerin karne notu ortalamaları arasında manidar bir fark olmadığ içerisinden seçkisiz yolla 6-B şubesi deney, 6-A şubesi kontrol grubu olarak belirlenmiştir. Sınıftaki öğrencilerin tümünün araştırmaya katılması sağlanmış ancak sürekli devamsızlık yapan, devamsızlık nedeni ile ön ve/veya son ölçümleri alınamayan ve ölçme araçlarını uygun 
biçimde doldurmayan öğrencilerden elde edilen veriler, veri çözümlemesi sırasında dikkate alınmamıştır. Veri toplama araçlarına göre çalışma grubunun deney grubuna ve cinsiyete göre dağ 11 ımı Tablo 3’te verilmiştir.

Tablo 3. Veri Toplama Araçlarına Göre Çalışma Grubunun Deney Grubuna ve Cinsiyete Göre Dağılımı

\begin{tabular}{|l|l|l|}
\hline Cinsiyet & Deney (6B) & Kontrol (6A) \\
\hline Kiz & 13 & 9 \\
\hline Erkek & 6 & 10 \\
\hline Toplam & 19 & 19 \\
\hline
\end{tabular}

\section{Uygulama}

Çalışmada, güvenilir sonuçlara ulaşmak için ayrılan süre ve içerik bakımından deneysel işleme uygun olması nedeni ile "Madde ve Isı" ünitesi seçilmiştir. Ön testlerin uygulanması, deneysel işlemler ve son testin uygulanması ile birlikte uygulama, 10 haftada tamamlanmıştır. Hatırda tutma düzeyini belirlemek için deney ve kontrol grubuna uygulamanın bitiminden 4 hafta sonra anlama düzeyi testi tekrar uygulanmıştır. Deney grubunda ADT'den not olan öğrenciler puanlara göre büyükten küçüğe göre sıralanmıştır. Deney grubundaki öğrencilerin zihinsel modellerinin gelişimini belirleyebilmek amacı ile en yüksek notu alan öğrenci, ortalarda notu olan öğrenci ve en düşük notu alan öğrenci belirlenmiştir. Bu öğrencilerle çalışma öncesinde ve sonrasında 40'ar dakikalık, zihinsel modellerine yönelik olarak görüşme yapılmıştır.

Deney grubuna uygulama öncesinde, yöntem ve uygulamalar hakkında bilgi sahibi olmaları için "Vücudumuzdaki Sistemler" ünitesinin "Solunum Sistemi" konusu 6 ders saati süresince MDÖY ile işlenmiştir. Ders planları ve materyaller HBAMD (2004) temel alınıp Ünal Çoban'ın (2009) yapmış olduğu eklemeler de göz önüne alınarak oluşturulmuştur. Deney grubu ile deneysel çalışma 16 ders saati sürmüştür. Deney grubunda öğretim süreci öğrencilerin ünite ile ilgili zihinsel modellerini belirlemek ve sahip oldukları zihinsel modellerle bütün olayları açıklayamayacaklarını göstermek amacıyla etkinliklerle başlatılmıştır. Etkinliklerin ardından soru-cevap ve tartışma tekniği ile öğrencilerin zihinlerinde modellerin temelleri atılmaya çalışılmış, yapılan bireysel etkinliklerle de öğrencilerin bu modelleri ifade etmeleri sağlanmıştır. Ardından kura ile sınıfta dört adet grup oluşturulmuş, grup üyelerinin tartışarak ortak bir model ortaya çıkartmaları sağlanmıştır. Gruplar sınıfta kendilerine verilen sürelerde modellerini sunmuşlardır. Sunum esnasında gerçekleştirilen tartışmalarda sınıfla ortak bir model oluşturulmuştur. Bu modellerden faydalanılarak düşünce deneyleriyle öngörülerde bulunmaya çalışılmıştır. Bu öngörüler deneysel olarak test edilmiş, deney sonuçlarından yararlanılarak modelin doğruluğuna ya da yanlışl1ğına karar verilmiştir. Oluşturulan modellerden yararlanılarak farklı problem durumları açıklanmaya çalışılmıştır. Son etapta oluşturulan modeller, ders kitabındaki modellerle karşılaştırılarak öğrencilerin farkındalık düzeyleri arttırılmaya çalışılmıştır. Kontrol grubu olarak atanan 6-A sınıfında "Madde ve Isl" ünitesi, 2011-2012 eğitim öğretim yılında yapılandırıcı yaklaşımı temel alan mevcut Fen ve Teknoloji öğretim programına göre işlenmiştir.

\section{Veri Toplama Araçları}

Çalışmada; öğrencilerin anlama ve hatırda tutuma düzeylerini ölçmek amacıyla araştırmacı tarafından geliştirilen “Anlama Düzeyi Testi” (ADT), yaratıcılıklarını ölçmek amacıyla "Torrance Şekilsel Yaratıcılık Testi A ve B", öğrencilerin zihinsel modellerini belirleyebilmek amacıyla araştırmacı tarafından hazırlanan "Madde ve Isı" görüşme formu veri toplama araçları olarak kullanılmıştır. 
Fen ve Teknoloji dersi ADT’si geliştirilirken, “Madde ve Isı” ünitesi ile ilgili anlama düzeylerini belirleme ve kavramsal bilgileri hatırda tutma düzeylerini belirlemek amacıyla araştırmacı tarafından hazırlanmıştır. Konuyla ilgili tüm kazanımları kapsayan çoktan seçmeli 34 soruluk deneme formu, daha önce bu üniteyi görmüş olan deney ve kontrol grubu dışındaki toplam 403 yedinci sınıf öğrencisine uygulanmıştır. Maddelerin güçlük indeksi ve ayırıcılık güçlük indeksleri hesaplanmıştır. Madde seçimi yapılırken orta güçlükteki maddelerin ve ayırt edicilik değeri 0.20'dan büyük olan maddelerin seçilmesine özen gösterilmiştir (Turgut, \& Baykul, 2012, 237; Tekin, 1993, 253-254). Kazanımlar açısından ulaşılabilirlik incelenirken, testlere verilen doğru yanıt frekans ve yüzde değerleri \%70 kritik değeri ile karşılaştırılmıştır (Büyüköztürk, 2010, 171). Kazanımlar arasında ön ilişkinin olup olmadığını araştırmak amacıyla tetrakorik korelasyon katsayısı kullanılmıştır. Belirlenen ölçütler ışı̆̆ında aynı kazanımı ölçen iki maddeden en iyi olan seçilerek, 17 maddenin yer aldığı Anlam Düzeyi Testi nihai formu elde edilmiştir. Testin KR20 güvenirlik kat sayısı 0,87 olarak bulunmuştur. Son şekli verilen ve geçerlilik güvenilirlik çalışması yapılan 17 maddelik anlama düzeyi testinin "Madde ve Isı" ünitesinde belirlenen kazanımları ölçtüğü ve güvenilirliğinin yüksek olduğu sonucuna varılmıştır.

Torrance Yaratıcılık Testi (TYT); sözel yaratıcılığı ve şekilsel yaratıcılığı ölçmek amacıyla iki bölümden oluşmaktadır (Torrance, 1966, 3-4). Araştırmada testin şekilsel yaratıcılık bölümü kullanılmıştır. Testin değerlendirilmesi, Torrance Tests of Creative Thinking, Booklet A ve B (1974, 1-3) puanlama rehberindeki kriterlere göre yapılmıştır. Orijinal testin güvenilirlik çalışmasında en düşük korelasyon katsayısının şekilsel akıcılığa (.50) ait olduğu görülmüştür. Aslan'da (2001, 24) Torrance Yaratıcılık Testi'ni Türkçe'ye uyarlayarak testin dilsel eşdeğerlilik, güvenirlik ve geçerlilik çalışmasını yapmıştır. Şekilsel akıcılık, şekilsel orijinallik, başlıkların soyutluluğu, zenginleştirme, erken kapamaya direnç puan türleri için şekilsel teste ait üç alt test için tüm yaş gruplarında $\mathrm{p}<0,01$ düzeyinde anlamlı sonuçlar elde edilmiştir. Elde edilen bulgular neticesinde Torrance Yaratıcı Düşünce Testi'nin Türkçe formunda şekilsel yaratıc1lıklarına ait alt testinin beklenen yaratıcı düşünce boyutlarını ölçtügüü kararına varılmıştır (Aslan, 2001, 25).

“Madde ve Isl” ünitesi görüşme formu; öğretim sürecinde öğrencilerin zihinsel modellerini nasıl etkilediğini belirleyebilmek amacıyla on adet sorudan oluşan araştırmacı tarafından hazırlanan bir görüşme formudur. Form geliştirilirken, hazırlanan taslak form Türkçe öğretmenleri ile alanda uzman kişilere okutulmuş ve deney grubunda yer almayan öğrencilerle ön görüşmeler gerçekleştirilmiştir. Yapılan öneriler ışığında formda gerekli düzeltmeler yapılmıştır.

\section{Verilerin Analizi}

Literatürde deney ve kontrol gruplarının her birinin büyüklüklerinin 15 ve daha üstü olması halinde parametrik bir istatistiğin uygulanmasının, analizde hesaplanacak anlamlılık düzeyinde önemli bir sapmaya yol açmadığına ilişkin araştırmalar vardır (Büyüköztürk, 2010, 8). Ön test son test kontrol gruplu desenlerde, araştırmacı uygulanan yöntemin etkili olup olmadığını hedeflemiş ise en uygun istatistiksel yöntem, ön testin ortak değişken olarak kontrol altına alındığı tek faktörlü ANCOVA'dır (Büyüköztürk, 2010, 48). Araştırmanın nicel boyutundaki alt problemlerin analizi tek faktörlü kovaryans analizi (ANCOVA) ile yapılmıştır. Sonuçların yorumlanmasında .05 anlamlılık düzeyi kabul edilmiştir.

Araştırmanın nitel bölümünde öğrencilerin zihinsel modellerini ortaya çıkartmak için yapılandırılmış görüşmeler düzenlenmiştir. Elde edilen veriler nitel araştırma tekniklerinden olgu bilim desenine uygun olarak betimlenmeye çalışılmıştır (Yıldırım, \& Şimşek, 2011, 79). 


\section{Bulgular}

a. Öğrencilerin MDFÖ Öncesindeki ADT Puanları Sabit Tutulduğunda, MDFÖ İle Çalışma Sonrasındaki ADT Puanları Arasındaki İlişki: Öğrencilerin son ADT puanları ile MDFÖ arasında anlamlı bir ilişkinin olup olmadığını anlamak için tek faktörlü kovaryans analizi (ANCOVA) yapılmış ve analizin bütün varsayımları kontrol edilmiştir. Öğrencilerin ön anlama testi puanlarına göre düzeltilmiş son anlama testi ortalama puanları Tablo 4'de verilmiştir. Buna göre son anlama testi ortalama puanları deney grubu için 10.73 ve kontrol grubu için 10.63 olarak hesaplanmıştır. Bu puanlara bakarak bir farkın olduğu düşünülebilir. Ancak grupların ön anlama testi puanları kontrol edildiğinde son anlama testi puanlarında değişme olduğu görülmektedir. Son anlama testi düzeltilmiş puanları deney grubu için 10.76 ve kontrol grubu için 10.60’tır.

Tablo 4. Son Anlama Testi Puanlarının Deney ve Kontrol Grubuna Göre Betimsel İstatistikleri

\begin{tabular}{|l|l|l|l|}
\hline & N & Ortalama & Düzeltilmiş Ortalama \\
\hline Deney & 19 & 10.73 & 10.76 \\
\hline Kontrol & 19 & 10.63 & 10.60 \\
\hline
\end{tabular}

Düzeltilmiş son test ortalama puanlarına göre deney grubunun son anlama testi puanın kontrol grubu son anlama testi puanından yüksek olduğu söylenebilir. Grupların düzeltilmiş son anlama testi ortalama puanları arasında gözlenen farkın anlamlı olup olmadığına ilişkin yapılan ANCOVA sonuçları Tablo 5'de verilmiştir.

Tablo 5. Ön Test Anlama Ölçeğine Göre Düzeltilmiş Son Test Anlama Puanlarının Gruplara Göre ANCOVA Sonuçları

\begin{tabular}{|l|l|c|l|l|l|}
\hline $\begin{array}{l}\text { Varyansın } \\
\text { Kaynağı }\end{array}$ & $\begin{array}{l}\text { Kareler } \\
\text { Toplamı }\end{array}$ & sd & Kareler Ortalaması & F & $\mathbf{p}$ \\
\hline Bağlılık (Reg.) & 28.604 & 1 & 28.604 & 4.779 & .036 \\
\hline Grup & .247 & 1 & .247 & .041 & .840 \\
\hline Hata & 209.502 & 35 & 5.986 & & \\
\hline Toplam & 238,211 & 37 & & & \\
${ }_{*}^{*}<.05$ & & & & & \\
\hline
\end{tabular}

ANCOVA sonuçlarına göre, deney ve kontrol grubu öğrencilerinin ön test anlama ölçeğine göre düzeltilmiş performans testi ortalama puanları arasında anlamlı bir fark olmadığ bulunmuştur, $\mathrm{F}(1,35)=.041, \mathrm{p}>.05$.

Sonuç olarak, Modellemeye Dayalı Öğretimin verilen mevcut öğretim yönteminden fark yaratacak şekilde öğrencilerin anlama düzeyleri üzerinde etki etmediği söylenebilir.

b. Öğrencilerin MDFÖ Öncesindeki Yaratıcılık Düzeyleri Puanları Sabit Tutulduğunda, MDFÖ İle Yaratıcılı Düzeyi Puanları Arasındaki İlişki: Öğrencilerin yaratııılık düzeyleri ile MDFÖ arasında anlamlı bir ilişkinin olup olmadığını anlamak için tek faktörlü kovaryans analizi (ANCOVA) yapılmış ve analizin bütün varsayımları kontrol edilmiştir. Öğrencilerin ön yaratıcılık testi puanlarına göre düzeltilmiş son yaratıcılık testi ortalama puanları Tablo 6' da verilmiştir. Buna göre son yaratıcılık testi ortalama puanları deney grubu için 8.81 ve kontrol grubu için 9.00 olarak hesaplanmıştır. Bu puanlara bakarak bir fark olduğu düşünülebilir. Ancak grupların ön yaratıcılık testi puanları kontrol edildiğinde son yaratıcılık testi puanlarında 
değişme olduğu görülmektedir. Son yaratıcılık testi düzeltilmiş puanları deney grubu için 9.03 ve kontrol grubu için 8.78'dir.

Tablo 6. Son Yaratıcılık Testi Puanlarının Deney ve Kontrol Grubuna Göre Betimsel İstatistikleri

\begin{tabular}{|l|l|l|l|}
\hline & $\mathbf{N}$ & Ortalama & Düzeltilmiş Ortalama \\
\hline Deney & 19 & 8.81 & 9.03 \\
\hline Kontrol & 19 & 9.00 & 8.78 \\
\hline
\end{tabular}

Düzeltilmiş son test ortalama puanlarına göre deney grubunun son yaratıcılık testi puanın kontrol grubu son yaratıcılık testi puanından yüksek olduğu söylenebilir. Grupların düzeltilmiş son yaratıcılık testi ortalama puanları arasında gözlenen farkın anlamlı olup olmadığına ilişkin yapılan ANCOVA sonuçları Tablo 7'de verilmiştir.

Tablo 7. Ön Test Yaratıcılık Ölçeğine Göre Düzenlenmiş Son Test Yaratıcılık Puanlarının Gruplara Göre ANCOVA Sonuçları

\begin{tabular}{|l|l|l|l|l|l|}
\hline $\begin{array}{l}\text { Varyansın } \\
\text { Kaynağı }\end{array}$ & $\begin{array}{l}\text { Kareler } \\
\text { Toplamı }\end{array}$ & sd & $\begin{array}{l}\text { Kareler } \\
\text { Ortalaması }\end{array}$ & $\mathbf{F}$ & $\mathbf{p}$ \\
\hline Bağlılık (Reg.) & 153.155 & 1 & 153.155 & 1.854 & .000 \\
\hline Grup & .593 & 1 & .593 & 71797.170 & .000 \\
\hline Hata & .000 & 35 & 8.262 & & \\
\hline Toplam & 153.508 & 37 & & & \\
\hline *p $<.05$ & & & & & \\
\hline
\end{tabular}

ANCOVA sonuçlarına göre, deney ve kontrol grubu öğrencilerinin ön test anlama ölçeğine göre düzeltilmiş son test ortalama puanları arasında anlamlı bir fark olduğu bulunmuştur, $\mathrm{F}(1,35)=71797.170, \mathrm{p}<.05$.

Buna bağlı olarak deney ve kontrol gruplarının düzeltilmiş yaratıcılık testi puanları arasında yapılan Bonferroni testi sonuçlarına göre, deney grubu öğrencilerinin yaratıcılık puanları ( $\mathrm{X}=$ 9.03), kontrol grubu öğrencilerinin yaratıcılık puanlarından $(X=8,78)$ daha yüksektir.

Sonuç olarak, Modellemeye Dayalı Öğretimin verilen mevcut öğretim yönteminden fark yaratacak şekilde öğrencilerin yaratıcılık düzeyleri üzerinde etki ettiği söylenebilir.

c. MDFÖ Sonunda Yapılan ADT Puanları Sabit Tutulduğunda, MDFÖ İle Bir Ay Sonra Gerçekleştirilen ADT Puanları Arasındaki İlişki: Öğrencilerin hatırda tutma düzeyleri ile MDFÖ arasında anlamlı bir ilişkinin olup olmadığını anlamak için tek faktörlü kovaryans analizi (ANCOVA) yapılmış ve analizin bütün varsayımları kontrol edilmiştir. Öğrencilerin son anlama testi puanlarına göre düzeltilmiş hatırda tutma testi ortalama puanları Tablo 7'de verilmiştir. Buna göre hatırda tutma testi ortalama puanları deney grubu için 8.52 ve kontrol grubu için 8.84 olarak hesaplanmıştır. Bu puanlara bakarak bir farkın olduğu düşünülebilir. Ancak grupların son anlama testi puanları kontrol edildiğinde hatırda tutma testi puanlarında değişme olduğu görülmektedir. Son anlama testi düzeltilmiş puanları deney grubu için 8.49 ve kontrol grubu için 8.87 'dir. 
Tablo 8. Hatırda Tutma Testi Puanlarının Deney ve Kontrol Grubuna Göre Betimsel İstatistikleri

\begin{tabular}{|l|l|l|l|}
\hline & $\mathbf{N}$ & Ortalama & Düzeltilmiş Ortalama \\
\hline Deney & 19 & 8.52 & 8.49 \\
\hline Kontrol & 19 & 8.84 & 8.87 \\
\hline
\end{tabular}

Düzeltilmiş son test ortalama puanlarına göre kontrol grubunun son hatırda tutma testi puanının deney grubu son hatırda tutma testi puanından yüksek olduğu söylenebilir. Grupların düzeltilmiş son anlama testi ortalama puanları arasında gözlenen farkın anlamlı olup olmadığına ilişkin yapılan ANCOVA sonuçları Tablo 9'da verilmiştir.

Tablo 9. Son Test Anlama Ölçeğine Göre Düzeltilmiş Hatırda Tutuma Test Puanlarının Gruplara Göre ANCOVA Sonuçları

\begin{tabular}{|l|l|l|l|l|l|}
\hline Varyansın Kaynağı & $\begin{array}{l}\text { Kareler } \\
\text { Toplamı }\end{array}$ & sd & $\begin{array}{l}\text { Kareler } \\
\text { Ortalaması }\end{array}$ & $\mathbf{F}$ & $\mathbf{p}$ \\
\hline Bağlılık (Reg.) & 68.302 & 1 & 68.302 & 12.925 & .001 \\
\hline Grup & 1.315 & 1 & 1.315 & .249 & .621 \\
\hline Hata & 184.962 & 35 & 5.285 & & \\
\hline Toplam & 254.211 & 37 & & & \\
\hline$* 0.05$ & & & & &
\end{tabular}

ANCOVA sonuçlarına göre, deney ve kontrol grubu öğrencilerinin son test anlama ölçeğine göre düzeltilmiş hatırda tutma testi ortalama puanları arasında anlamlı bir fark olmadığ bulunmuştur, $\mathrm{F}(1,35)=.621, \mathrm{p}>.05$.

Sonuç olarak, Modellemeye Dayalı Öğretimin verilen mevcut öğretim yönteminden fark yaratacak şekilde öğrencilerin hatırda tutma düzeyleri üzerinde etki etmediği söylenebilir.

d. MDFÖ Uygulandığı Deney Grubu Öğrencilerinin Çalışma Öncesindeki Zihinsel Modelleri İle Çalışma Sonrasındaki Zihinsel Modelleri Arasındaki Farklılıklar: Görüşme formunun birinci sorusu "Arkadaşınız ısı kavramını nasıl tanımlayacağını bilmemektedir ve sizden kendisine yardım etmenizi istemektedir? Arkadaşınıza ısıyı nasıl tanımlarsınız?" şeklinde sorulmuştur. Birinci sorunun amacı öğrencilerin ısıya ilişkin sahip oldukları zihinsel modelleri açığa çıkarmaktır.

Tablo 10. Çalışma Öncesi ve Sonrası Birinci Soruya Verilen Cevaplar

\begin{tabular}{|c|c|c|}
\hline Öğrenci & Çalışma Öncesi & Çalışma Sonrası \\
\hline Y.P. & $\begin{array}{l}\text { Maddenin sıcaklığ } 46{ }^{\circ} \mathrm{C} \text { olsun diğeri de } \\
20{ }^{\circ} \mathrm{C} \text { olsun iki maddeyi temas ettirdiğimiz } \\
\text { zaman sıcaklığı çok olan az olana bir şey } \\
\text { verir, verdiği isı olarak tanımlanır. }\end{array}$ & $\begin{array}{l}\text { Bir cismin sıcaklı̆̆ının artmasını sağlayan } \\
\text { enerjiye 1S1 denir. Örneğin iki tane maddeyi } \\
\text { alalım. Biri daha soğuk biri daha sıcak ve } \\
\text { onları birbirine değdirdiğimiz zaman sıcak } \\
\text { olan soğuk olana 1sı verir. Bu olay ikisinin } \\
\text { sıcaklığı eşitleninceye kadar devam eder. }\end{array}$ \\
\hline O.P. & Isı bir enerji türüdür. & Bir cismin sıcaklığını arttıran enerji türüdür. \\
\hline D.P. & $\begin{array}{l}\text { Kaynayan su altındaki ateş onu 1sitır ve } \\
\text { 1sınma olayı gerçekleşir. Dışarı bırakılan } \\
\text { sular, güneş dolayısıyla 1sınabilir. Ben bunu } \\
\text { yaşadım. Yaz tatilinde hava çok sıcak } \\
\text { olduğunda dışarıya bidonla su koyduk. 3-4 } \\
\text { saat sonra aldığımızda sıcak su olmuşlardı. } \\
\text { Isı, buharlaşarak köpürür. }\end{array}$ & $\begin{array}{l}\text { Bir cismin sıcaklığının artmasına ya da } \\
\text { azalmasını sağlayan şeye 1sı denir. }\end{array}$ \\
\hline
\end{tabular}

Y.P: Yüksek Puan Alan Öğrenci, O.P: Orta Puan Alan Öğrenci, D.P: Düşük Puan Alan Öğrenci 
Birinci soruya verilen cevaplar dikkate alındığında yüksek puan alan öğrencinin öğretim süreci öncesinde 1sıyı, zihninde sıcaklıkları farklı olan maddeler arasında alınıp verilen bir şey olarak modellediği, çalışma sonrasında ise 1sıyı, sıcaklıkları farklı maddeler arasında alınıp verilen bir enerji türü olarak modellediği gözlemlenmiştir. Orta düzey puan alan öğrencinin ise çalışma öncesinde 1sıyı zihninde sadece bir enerji türü olarak modellerken öğretim süreci sonunda sıcaklığ değiştirebilen bir enerji türü şeklinde modellediği gözlemlenmiştir. Düşük puan alan öğrencinin öğretim süreci öncesinde 1sıyı tanımlamada başarılı olamadığı gözlemlenmiştir. Öğretim süreci sonrasında ise düşük puan alan öğrencinin 1sıyı zihninde sıcaklığı değiştiren bir şey olarak modellediği gözlemlenmiştir.

Görüşme formunun ikinci sorusu "Arkadaşınız sıcaklık kavramını nasıl tanımlayacağını bilmemektedir ve sizden kendisine yardım etmenizi istemektedir? Arkadaşınıza sıcaklı̆̆ nasıl tanımlarsınız?" şeklinde sorulmuştur. İkinci sorunun amacı öğrencilerin sıcaklığa ilişkin sahip oldukları zihinsel modelleri açığa çıkarmaktır.

Tablo 11. Çalışma Öncesi ve Sonrası İkinci Soruya Verilen Cevaplar

\begin{tabular}{|c|l|l|}
\hline Öğrenci & Çalışma Öncesi & Çalışma Sonrası \\
\hline Y.P. & $\begin{array}{l}\text { Sicaklık bir maddenin ne kadar ısı aldığını } \\
\text { gösteren şeydir. }\end{array}$ & $\begin{array}{l}\text { Bir cismin 1sı aldığı zaman gösterdiği } \\
\text { tepkiye sıcaklık denir. Sıcaklık her } \\
\text { maddede görülen bir tepkidir. }\end{array}$ \\
\hline O.P. & $\begin{array}{l}\text { Bir maddedeki taneciklerden birinin ortalama } \\
\text { hareket enerjisinin ifade edilmesidir. Sıcaklık } \\
\text { enerji değildir. Termometre ile ölçülür. }\end{array}$ & $\begin{array}{l}\text { Sicaklık enerji değildir. Isının etkisiyle } \\
\text { sicaklık oluşur. }\end{array}$ \\
\hline D.P. & $\begin{array}{l}\text { Dünyanın derecesi ne kadar fazla ise sıcaklı̆̆ı } \\
\text { o kadar fazla olur. Derece ne kadar düşük } \\
\text { olursa hava soğur. Sıcaklık, çiçekleri } \\
\text { büyüten, bitkileri canlandın şey. Denizin ya } \\
\text { da havanın soğuk olmasına neden olan şey. }\end{array}$ & $\begin{array}{l}\text { Bir cismin 1sısının artması ya da azalması } \\
\text { ile gerçekleşen fiziksel değişimine } \\
\text { sicaklık denir. }\end{array}$ \\
\hline
\end{tabular}

Y.P: Yüksek Puan Alan Öğrenci, O.P: Orta Puan Alan Öğrenci, D.P: Düşük Puan Alan Öğrenci

İkinci soruya verilen cevaplar dikkate alındığında yüksek ve orta düzey puan alan öğrenciler, çalışma öncesi ve sonrasında 1sı ile sıcaklık arasındaki ilişkiden yararlanarak zihinlerinde bir sıcaklık modeli oluşturmuşken, düşük puan alan öğrenci çalışma öncesinde sahip olduğu "sıcaklık bitkileri canlandıran, çiçekleri büyüten, denizlerin ya da havanın soğuk olmasını sağlayan şey" modelini 1s1 sicaklık ilişkisini baz alan zihinsel bir modelle değiştirdiği gözlemlenmiştir.

Görüşme formunun üçüncü sorusu "Canınız makarna yemek istedi ve mutfağa gidip bir tencereye su koyup ocă̆ yaktınız. Bir süre sonra kapağın tıkırdayarak ses çıarmaya başladığını duydunuz. Kapă̆ın bir süre sonra tıkırdamasını nasıl açıklarsınız?" şeklinde sorulmuştur. Üçüncü sorunun amacı öğrencilerin ısınan taneciklerin hareketine ilişkin sahip oldukları zihinsel modelleri açığa çıkarmaktır. 
Tablo 12. Çalışma Öncesi ve Sonrası Üçüncü Soruya Verilen Cevaplar

\begin{tabular}{|c|c|c|}
\hline Öğrenci & Çalışma Öncesi & Çalışma Sonrası \\
\hline Y.P. & $\begin{array}{l}\text { Tencerenin içindeki suya ocak 1sı veriyor. } \\
\text { Isınan sudan gaz kabarcı̆ı çıkar. Kabarcıklar } \\
\text { hızlanırlar ve kapağa çarparlar. Böylelikle } \\
\text { kapak tıkırdar. }\end{array}$ & $\begin{array}{l}\text { Annelerimizin makarna yaptıkları } \\
\text { tencereler metaldendir. Metaller iyi bir ısı } \\
\text { iletkeni olduğu için ocaktaki ateşin verdiği } \\
\text { 1sıyı alır ve tencerenin içindeki suya iletir. } \\
\text { Su ısı aldığı için gaz haline geçmek ister. } \\
\text { Su kaynamaya ve fokurdamaya başlar. } \\
\text { Kapak kapalı olduğu içinde ses çıkartır. }\end{array}$ \\
\hline O.P. & $\begin{array}{l}\text { Tencere iletken bir maddedir. Bu yüzden } \\
\text { suya 1sı iletir. Bu sayede su kaynar ve } \\
\text { buharlaşır. Buhar kapağa çarpar ve ses } \\
\text { çıarır. }\end{array}$ & $\begin{array}{l}\text { Tencere ısı iletimi yaparak ısıyı suya iletir. } \\
\text { Su kaynamaya başlar. Sonra su } \\
\text { buharlaşarak tıkırdamaya yol açar. }\end{array}$ \\
\hline D.P. & $\begin{array}{l}\text { Altındaki ateş suyu 1sıtıyor. Su 1sındı ğ için } \\
\text { kabarcıklar çıkıor. Kabarcıklar ses yapar. } \\
\text { Aşırı ısınan şey tencereyi bile oynatıyor }\end{array}$ & $\begin{array}{l}\text { Makarna kaynayarak ısınıyor, içindeki } \\
\text { sıcaklık dışarı çıkmak istediği için tıkırtılar } \\
\text { çıkartıyor. }\end{array}$ \\
\hline
\end{tabular}

Y.P: Yüksek Puan Alan Öğrenci, O.P: Orta Puan Alan Öğrenci, D.P: Düşük Puan Alan Öğrenci

Üçüncü soru için verilen cevaplar incelendiğinde öğrencilerin öğretim süreci öncesi ve sonrasında maddenin hallerinde sıvıdan gaza doğru geçildiğinde maddenin hareketinin arttığı yönde bir zihinsel modele sahip oldukları gözlenmektedir. Cevaplar irdelendiğinde öğretim süreci sonrasında öğrencilerin ilgili olayları açıklamak için zihinlerinde iletken madde modeli oluşturdukları gözlemlenir.

Görüşme formunun dördüncü sorusu "Soğuk bir kış gününde kombinizi yaktınız, odanızın sıcaklığ $25{ }^{\circ} \mathrm{C}$ sıcaklı̆̆a ulaştıktan kısa bir süre sonra kombinizden garip sesler çıkardıktan sonra bozuldu ve odanızın sıcaklı̆̆ $10^{\circ} \mathrm{C}$ kadar düştü. Odanızın slcaklığının düşmesini nasıl açıklarsınız?" şeklinde sorulmuştur. Dördüncü sorunun amacı öğrencilerin 1sının ortamlar arasında taşınmasına ilişkin zihinsel modellerini açığa çıkarmaktır.

Tablo 13. Çalışma Öncesi ve Sonrası Dördüncü Soruya Verilen Cevaplar

\begin{tabular}{|c|c|c|}
\hline Öğrenci & Çalışma Öncesi & Çalışma Sonrası \\
\hline Y.P. & $\begin{array}{l}\text { Kaloriferden gelen ısı odayı 1sıtır. Bu } \\
\text { nedenle odanın 1sısı artar. Kombi bo- } \\
\text { zulduğunda odanın içerisindeki ısı mik- } \\
\text { tarı düşer dolayısıyla sıcaklık düşer. }\end{array}$ & $\begin{array}{l}\text { Kombiyi yaktığımızda kombinin verdiği 1s1 } \\
\text { odaya dağıldı ve odayı 1sıttı. Ancak kombi } \\
\text { bozulduğunda odaya 1S1 verecek bir 1S1 kaynağ1 } \\
\text { olmadığ } 1 \text { için odanın sıcaklığ } 1 \text { azald1. }\end{array}$ \\
\hline O.P. & $\begin{array}{l}\text { Kombi bozulmadan önce sicaklık } \\
\text { artmışt, kombi bozulunca sicaklıkta } \\
\text { düşüş oldu. }\end{array}$ & $\begin{array}{l}\text { Isı yalıtımlı bir evde } 1 \mathrm{~S} 125^{\circ} \mathrm{C} \text { dereceyken kombi } \\
\text { bozulduğunda } 10^{0} \mathrm{C} \text { kadar düşmesini, odadaki } \\
\text { hava taneciklerinin hareketlerinin ve taneciklerin } \\
\text { arasındaki mesafenin azalması ile açıklarız. }\end{array}$ \\
\hline D.P. & $\begin{array}{l}\text { Doğal gaz yakıldığında odaya 1sı verir } \\
\text { ve oda sıcaklığını arttırır. Kombi bo- } \\
\text { zulduğu zaman odaya 1sı vermemeye } \\
\text { başlar ve oda eski haline döner }\end{array}$ & $\begin{array}{l}\text { Soğuk bir kış gününde yaktığımız soba evimizin } \\
\text { ısısını hiç olmadığı kadar yükseltir fakat kombi } \\
\text { bozulduğundan itibaren evin ısısı dışarı çıarak } \\
\text { en yakın zamanda eski haline gelir. }\end{array}$ \\
\hline
\end{tabular}

Y.P: Yüksek Puan Alan Öğrenci, O.P: Orta Puan Alan Öğrenci, D.P: Düşük Puan Alan Öğrenci

Dördüncü soruya verilen cevaplar incelendiğinde öğrenim süreci öncesinde öğrencilerin 1S1 kaynağının 1S1 verdiği süreçte ortam sıcaklığının arttığ1 ancak 1S1 kaynağı olmadığında 1sının 
düştüğü yönünde (ancak 1sıya ne olduğunu açıklamıyor) bir zihinsel modele sahip oldukları gözlemlenir. Çalışma sonrasında yüksek puan alan öğrencinin ısının odada yayıldığı yönünde, orta düzey puan alan öğrencinin maddenin tanecikli yapısından yararlandığı ve düşük puan alan öğrencinin de ısının çok olan yerden az olan yere doğru hareket ettiğine değinerek zihinsel modellerini geliştirdikleri gözlemlenmiştir.

Görüşme formunun beşinci sorusu "Anneniz eve gelen misafirlere Türk kahvesi pişirirken sizden ocağın üzerindeki kahveyi karıştırarak kendisine yardım etmenizi istiyor. Çay kaşı̆̆g ile kahveyi karıştırmaya çalıştığınızda birkaç dakika sonra eliniz yanıyor bunun üzerine çay kaşı̆̆ yerine yemek kaşığ kullanıyorsunuz. Aradan beş dakika geçince tekrar yanıyor. Bunun üzerine tahta kaşık kullanarak eliniz yanmadan kahveyi pişirebiliyorsunuz. Çay ve yemek kaşıklarında elinizin farklı sürelerde yanmasını, tahta kaşıkta ise yanmamasını nasıl açıklarsın?" şeklinde sorulmuştur. Beşinci sorunun amacı öğrencilerin yalıtkan ve iletkenlere ilişkin zihinsel modellerini ortaya çıkarmaktır.

Tablo 14. Çalışma Öncesi ve Sonrası Beşinci Soruya Verilen Cevaplar

\begin{tabular}{|c|c|c|}
\hline Öğrenci & Çalışma Öncesi & Çalışma Sonrası \\
\hline Y.P. & $\begin{array}{l}\text { Kaşılların yapıldığı madde farklı. Bu } \\
\text { nedenle aldıkları ısı miktarı farklı } \\
\text { olabilir. Bu nedenle elimiz farklı } \\
\text { sürelerde yanar. Bir de metaller belki } \\
\text { 1sının iletilmesini sağlar. }\end{array}$ & $\begin{array}{l}\text { Çay kaşığının hem küçük hem de 1sıyı iyi } \\
\text { iletmesinden dolayı elimiz kısa sürede } \\
\text { yanar. Yemek kaşığı daha büyük olduğu için } \\
\text { yemek kaşığını daha uzun süre tutabiliriz. } \\
\text { Tahta kaşık 1sıyı iyi iletmediği için elimiz } \\
\text { yanmaz. }\end{array}$ \\
\hline O.P. & $\begin{array}{l}\text { Metal kaşıklar iletken maddelerdir. Isıyı } \\
\text { rahatlıkla ilettikleri için elimiz yanar. } \\
\text { Tahta kaşık yalıtkan bir madde olduğu } \\
\text { için 1sıyı iletmez ve elimiz yanmaz. Çay } \\
\text { kaşığı daha kısadır, bu nedenle daha kısa } \\
\text { tutabiliriz. }\end{array}$ & $\begin{array}{l}\text { Metal kaşık iletken olduğu için elimize 1sıyı } \\
\text { derhal iletir. Küçük metal kaşıla büyük } \\
\text { metal kaşık arasındaki fark ısının küçük } \\
\text { kaşıkta aldığı yolun daha kısa olmasıdır. } \\
\text { Tahta kaşı yalıtkan olduğu için ısıyı } \\
\text { iletmez. }\end{array}$ \\
\hline D.P. & $\begin{array}{l}\text { Çay kaşığı daha küçük olduğu için } \\
\text { elimize buhar geliyor. Yemek kaşığı } \\
\text { büyük olduğu için buhar elimize daha geç } \\
\text { geliyor. Tahta kaşıkda ise sıcaklık } \\
\text { elimize vurmuyor. }\end{array}$ & $\begin{array}{l}\text { Çay ve yemek kaşıkları ısıyı farklı sürelerde } \\
\text { iletirdi. Çay kaşığı kısa olduğu için ısı } \\
\text { hemen elime gelirdi. Tahta kaşık } \\
\text { kullanıldığında elim yanmazdı. tahta kaşık } \\
\text { yalıtkan olduğu için aldığı 1sıyı diğer } \\
\text { maddelere geçirmez. }\end{array}$ \\
\hline
\end{tabular}

Y.P: Yüksek Puan Alan Öğrenci, O.P: Orta Puan Alan Öğrenci, D.P: Düşük Puan Alan Öğrenci

Beşinci soruya verilen cevaplar incelendiğinde yüksek puan alan ve orta düzey puan alan öğrencilerin öğretim süreci öncesi ve sonrasında ısının iletiminde maddenin türünün ve büyüklüğünün önemli olduğuna ilişkin zihinsel modellere sahiptirler. Düşük puan alan öğrencinin çalışma öncesinde elimizin yanmasını kaşığın büyüklüğü ve iletkenliği ile açıklamak yerine buharlaşma ile açıkladığı gözlenmektedir. Çalışma sonrasında düşük puan alan öğrencinin olayı açıklamak için metallerde 1sı iletimine ve kaşık boyuna dayalı bir zihinsel model geliştirdiği görülmektedir.

Görüşme formunun altıncı sorusu "Sizce güneş dünyamızı nasıl ısıtmaktadır?" şeklinde sorulmuştur. Altıncı sorunun amacı öğrencilerin 1sının 1şıma yoluyla taşınmasına ilişkin zihinsel modellerini açığa çıkarmaktır. 
Tablo 15. Çalışma Öncesi ve Altıncı Soruya Verilen Cevaplar

\begin{tabular}{|c|c|c|}
\hline Öğrenci & Çalışma Öncesi & Çalışma Sonrası \\
\hline Y.P. & $\begin{array}{l}\text { Güneş belki dünyamızı 1şınlar vererek 1sıtır. } \\
\text { Güneşten uzaklaştığımızda 1şık miktarı } \\
\text { azalır, bu nedenle ısınma azalır. }\end{array}$ & $\begin{array}{l}\text { Güneş ışıma yolu ile 1şınlarını diğer } \\
\text { gezegenlere yayar. Işınlar gezegenlere } \\
\text { ulaştığında gezegenleri de 1sıtmış olur. }\end{array}$ \\
\hline O.P. & Güneş dünyamızı yaydığı 1şınlarla 1sıtır. & Güneş 1şınları ile dünyamızı 1sıtır. \\
\hline D.P. & $\begin{array}{l}\text { Güneş dünyaya ne kadar yaklaşırsa o kadar } \\
\text { 1sıtır, ne kadar uzaklaşırsa o kadar soğutur. } \\
\text { Mesafe arttıkça 1sınma miktarı da azalır. }\end{array}$ & $\begin{array}{l}\text { Dünyamız güneş etrafında dönerken } \\
\text { güneşin ışığıyla ısınır. }\end{array}$ \\
\hline
\end{tabular}

Y.P: Yüksek Puan Alan Öğrenci, O.P: Orta Puan Alan Öğrenci, D.P: Düşük Puan Alan Öğrenci

Altıncı soruya verilen cevaplar incelendiğinde çalışma öncesinde ve sonrasında öğrencilerin güneşin dünyayı 1şınları ile 1sıttığı yönünde zihinsel modele sahip oldukları görülmektedir. Yüksek ve düşük puan alan öğrencilerin çalışma öncesinde güneşe yakınlık ile 1sınma miktarı arasında ilişki kurdukları bir zihinsel modele sahip oldukları gözlemlenmektedir. Düşük puan alan öğrencinin öğretim süreci sonucunda zihinsel modelini dünyanın hareketini de ekleyerek geliştirdiği gözlemlenmiştir.

Görüşme formunun yedinci sorusu "Sizce neden kışın koyu renkli klyafetler giyerken, yazın açık renkli kiyafetler giyeriz?” şeklinde sorulmuştur. Yedinci sorunun amacı öğrencilerin soğurulma ve yansıma olaylarına ilişkin sahip oldukları zihinsel modelleri açığa çıkarmaktır.

Tablo 16. Çalışma Öncesi ve Yedinci Soruya Verilen Cevaplar

\begin{tabular}{|c|c|c|}
\hline Öğrenci & Çalışma Öncesi & Çalışma Sonrası \\
\hline Y.P. & $\begin{array}{l}\text { Koyu renkli kıyafetler yazın daha çok } \\
\text { 1sınmamıza neden olur. Bu nedenle yazın } \\
\text { koyu renkli kıyafet giymeyiz. Yazın daha az } \\
\text { 1şık alan beyaz renkli kıyafetler giyeriz. }\end{array}$ & $\begin{array}{l}\text { Kışıı koyu renkli kıyafetler giyeriz çünkü } \\
\text { koyu renkler } 1 \text { şığı emerek 1sıyı } \\
\text { hapsederler. }\end{array}$ \\
\hline O.P. & $\begin{array}{l}\text { Çünkü siyah renkler güneş ışı̆̆ını daha çok } \\
\text { çeker bu nedenle çok 1sınırı. Açık renkli } \\
\text { kıyafetler güneş 1şığını daha az çektiği için } \\
\text { yazın açık renkli kıyafetler giyeriz }\end{array}$ & $\begin{array}{l}\text { Koyu renkli kıyafetler güneş ışı̆̆ını } \\
\text { çekerek ısınırlar. Bu nedenle kışın koyu } \\
\text { renk giyerken, yazın açık renkli kıyafet } \\
\text { giyeriz. }\end{array}$ \\
\hline D.P. & $\begin{array}{l}\text { Koyu renkler daha sıcak tutar ve yünlü olur. } \\
\text { Açık renkliler daha incedir ve fazla } \\
\text { 1sıtmazlar. }\end{array}$ & $\begin{array}{l}\text { Koyu renkli kıyafetler daha iyi ısınıyor bu } \\
\text { nedenle kışın koyu renkli kıyafetler } \\
\text { giyeriz. }\end{array}$ \\
\hline
\end{tabular}

Y.P: Yüksek Puan Alan Öğrenci, O.P: Orta Puan Alan Öğrenci, D.P: Düşük Puan Alan Öğrenci

Yedinci soruya verilen cevaplar incelendiğinde yüksek ve orta düzey puan alan öğrencilerin öğretim sürecinin başında ve sonunda koyu renkli kıyafetlerin 1şı̆̆ daha çok soğurduğu yönünde zihinsel modellere sahip olduğu gözlemlenmektedir. Düşük puan alan öğrencinin ise çalışma öncesinde koyu renkli kıyafetlerin daha sıcak tuttuğu ve kalın olduğu yönündeki zihinsel modelini çalışma sonrasında koyu renkli kıyafetlerin daha iyi ısındığı yönünde bir zihinsel modelle geliştirdiği gözlemlenmiştir.

Görüşme formunun sekizinci sorusu "Sizce elektrikli ısitıclların arka yüzeyi neden parlak maddelerle kaplanır?" şeklinde sorulmuştur. Sekizinci sorunun amacı öğrencilerin ısının yansıtılmasına ilişkin zihinsel modellerini açığa çıkarmaktır. 
Tablo 17. Çalışma Öncesi ve Sekizinci Soruya Verilen Cevaplar

\begin{tabular}{|c|c|c|}
\hline Öğrenci & Çalışma Öncesi & Çalışma Sonrası \\
\hline Y.P. & $\begin{array}{l}\text { Parlak maddeler dışarıdan alınan ısının } \\
\text { içeriye girmesini engeller. Isı, ısıtıcının } \\
\text { ç̧ine girmesin diye kaplanır. }\end{array}$ & Parlak maddeler ısıyı dışarı iletmezler. \\
\hline O.P. & $\begin{array}{l}\text { Termosun içindeki ayna sıcaklığı yansıtır } \\
\text { ve suyun sıcak kalmasını sağlar. Metaller } \\
\text { de iletken olduğu için ısıyı çekerek } \\
\text { hapseder. }\end{array}$ & $\begin{array}{l}\text { Elektrikli isıtıcılar parlak maddelerle } \\
\text { kaplanır çünkü parlak yüzeyler isıyı } \\
\text { yansıtarak daha fazla ısıtma sağlarlar. }\end{array}$ \\
\hline D.P. & $\begin{array}{l}\text { Parlak madde ile kaplıdır çünkü ısıtıcı çok } \\
\text { 1S1 verdiği zaman kendini yakabilir. Parlak } \\
\text { madde yangını önler. }\end{array}$ & $\begin{array}{l}\text { Hem yangindan korur hem de } 1 \text { siyı daha iyi } \\
\text { iletmeye yarar }\end{array}$ \\
\hline
\end{tabular}

Y.P: Yüksek Puan Alan Öğrenci, O.P: Orta Puan Alan Öğrenci, D.P: Düşük Puan Alan Öğrenci

Sekizinci soruya verilen cevaplar incelendiğinde çalışma öncesinde ve sonrasında yüksek ve düşük puan alan öğrencilerin elektrikli 1sıtıcılarda parlak yüzeylerin güvenlik amaçlı kullanıldığ yönünde bir zihinsel modele sahip oldukları gözlemlenirken, orta düzey puan alan öğrencinin çalışma öncesinde ve sonrasında parlak yüzeylerin yansıtma amaçlı olarak kullanıldığı yönünde bir zihinsel modele sahip olduğu gözlemlenmiştir.

Görüşme formunun dokuzuncu sorusu "Karalar denizlere göre çabuk ısınır, çabuk soğurlar. Sonbaharda rüzgâr sicak olan denizlerden, soğuk olan karalara doğru eser. Bu bilgileri göz önünde bulundurduğunuzda rüzgârların oluşumunu nasıl açıklarsınız?" şeklinde sorulmuştur. Dokuzuncu sorunun amacı öğrencilerin ısının konveksiyonla iletilmesine ilişkin zihinsel modellerini ortaya çıkarmaktır.

Tablo 18. Çalışma Öncesi ve Dokuzuncu Soruya Verilen Cevaplar

\begin{tabular}{|c|c|c|}
\hline Öğrenci & Çalışma Öncesi & Çalıșma Sonrası \\
\hline Y.P. & $\begin{array}{l}\text { Güneş ışılnları ile oluşan bir hava } \\
\text { olayıdır. }\end{array}$ & $\begin{array}{l}\text { Rüzgârlar şöyle oluşur: denizin üzerindeki hava is1 } \\
\text { alarak hareketini artırarak yukarı doğu çıkarken, } \\
\text { karaları üzerindeki hava hareketini azaltarak } \\
\text { aşağı iner. Denizin üzerinde boşalan yere } \\
\text { karadaki hava gelir. }\end{array}$ \\
\hline O.P. & Bir fikrim yok. & $\begin{array}{l}\text { Rüzgârlar isının konveksiyon yolu ile iletilmesi } \\
\text { sonucu oluşur. }\end{array}$ \\
\hline D.P. & Bir fikrim yok. & $\begin{array}{l}\text { Bir taraf sıcak bir taraf soğuk olduğu için iki yeri } \\
\text { aynı sıcaklığa getirmek için yani dağlarla denizlerin } \\
\text { sicaklığını aynı yapmak için rüzgâr olayı meydana } \\
\text { gelir ve hava akımı oluşur. }\end{array}$ \\
\hline
\end{tabular}

Y.P: Yüksek Puan Alan Öğrenci, O.P: Orta Puan Alan Öğrenci, D.P: Düşük Puan Alan Öğrenci

Öğrencilerin dokuzuncu soruya verdikleri cevaplar incelendiğinde öğretim süreci öncesinde rüzgâra güneşin neden olduğu yönünde bir zihinsel modele sahip olduğu gözlemlenmekte iken, orta düzey ve düşük düzey puan alan öğrencilerin soruya cevap veremedikleri gözlemlenmektedir. Öğrenim süreci sonunda yüksek puan alan öğrenci zihinsel modelini konveksiyon ile iletimin ilkelerine göre geliştirirken, orta düzey puan alan öğrenci konveksiyon ile iletime ilişkin yeni bir zihinsel model oluşturmuştur. Düşük puan alan öğrenci ise rüzgârı sıcaklıkların eşitlenmesi üzerine kurduğu bir zihinsel modelle açıklamaya çalışmıştır.

Görüşme formunun onuncu sorusu "Yalıtımı nasil tanımlarsınız ve sizce yalıtım neden 
önemlidir?" şeklinde sorulmuştur. Onuncu sorunun amacı öğrencilerin 1s1 yalıtımına ilişkin zihinsel modellerini ortaya çıkarmaktır.

Tablo 19. Çalışma Öncesi ve Onuncu Soruya Verilen Cevaplar

\begin{tabular}{|c|c|c|}
\hline Öğrenci & Çalışma Öncesi & Çalışma Sonrası \\
\hline Y.P. & $\begin{array}{l}\text { Bir maddeden başka maddeye 1S1 } \\
\text { geçişini engellemek. }\end{array}$ & $\begin{array}{l}\text { Is1 yalıtımı bizler için çok önemlidir çünkü } \\
\text { bizim işlerimizi kolaylaştırır. Mesela } \\
\text { tencerenin kulpları plastiktir. Bu sicak } \\
\text { tencereyi taşırken ellerimizi yakmayı önler. } \\
\text { Is1 yalıtımı genellikle mutfaklarda yapilır. } \\
\text { Firında ve buzdolabında is1 yalıtımı vardır. } \\
\text { Evlerin mantoluma işleminde 1S1 yalıtımı } \\
\text { gerçekleştirilir. }\end{array}$ \\
\hline O.P. & $\begin{array}{l}\text { Isı yalıtımı özellikle binalarda } \\
\text { kullanıılır. Yalıtkan maddeler ısının } \\
\text { geçişini önler. Bir binanın ısı } \\
\text { yalıtıanı maddelerle kaplanmasına } \\
\text { yalıtım denir. }\end{array}$ & $\begin{array}{l}\text { Isı yalıtımı evleri kaplamada kullanılır. Isı } \\
\text { yalıtımı dışarıdaki ssıyı içeri almaz, içerdeki } \\
\text { 1sıyı dışarı çıkarmaz. Isı yalıtım } \\
\text { malzemelerine örnek olarak: taş yünü, strafor } \\
\text { köpük. }\end{array}$ \\
\hline D.P. & Bir fikrim yok. & Bir fikrim yok. \\
\hline
\end{tabular}

Y.P: Yüksek Puan Alan Öğrenci, O.P: Orta Puan Alan Öğrenci, D.P: Düşük Puan Alan Öğrenci

Onuncu soruya verilen öğretim süreci öncesindeki cevaplar incelendiğinde yüksek puan alan ve orta düzey puan alan öğrencilerin zihinsel modellerini yalıtımı 1sı geçişini önlemek olarak oluşturdukları, üç numaralı öğrencinin ise soruya cevap veremediği gözlemlenmektedir. Öğrenim süreci sonunda yüksek ve orta düzey puan alan öğrenciler 1sı yalıtımının kullanıldığı alanlardan faydalanarak zihinsel modellerini geliştirdikleri gözlemlenmiştir.

Sonuç itibariyle araştırmacı tarafından öğretim süreci içerisinde görüşme yapılan öğrencilerin sahip oldukları zihinsel modelleri deneyimleriyle geliştirdikleri, değiştirdikleri, yeni modeller oluşturdukları gözlenmiştir.

\section{Tartışma}

Uygulama öncesindeki deney ve kontrol grubu öğrencilerinin ön ADT puanları sabit tutulduğunda, MDFÖ ile öğrencilerin son ADT puanları arasında anlamlı bir ilişki bulunmamıştır. Öğrencilerin anlama düzeylerine ulaşabilmeleri için, öğrendikleri yeni bilgiler ile eski bilgiler arasında bağ kurabilmeleri gerekir (Anderson, et alii., 2010, 91). HBAMD (2004, 193-215) keşfetme, model oluşturma ve model formülasyonu basamaklarında gerçekleştirilen etkinliklerin öğrencilerin sahip oldukları zihinsel modelleri ortaya çıkarmalarını sağlayarak, bu modeller üzerine yeni zihinsel modeller oluşturmaları için firsat vermektedir. Literatür incelendiğinde MDFÖ'nün öğrencilerin anlamlı öğrenmeyi gerçekleştirmede olumlu yönde etkilediğini gösteren çalışmalar bulunmaktadır (Frederiksen, et alii., 1998, 806; Barab, et alii., 2000, 719). Bu bulgulardan yola çıkarak MDFÖ'nün öğrencilerin anlama düzeylerini olumlu yönde etkilemesi beklenmektedir. Buna karşın gerçekleştirilen çalışmada MDFÖ ile öğrencilerin anlama düzeyleri arasında anlamlı bir ilişki bulunamamıştır. Yapılandırmacı yaklaşımın temelinin öğrenenin, kendi bilgilerini gene kendi yapılandırması gerektiği düşüncesine dayanmaktadır ve literatürdeki çalışmalar incelendiğinde yapılandırmacı yaklaşıma dayanan 5E modelinin de öğrencilerin anlamlı öğrenmelerini olumlu yönde etkileyen çalışmalara rastlanmaktadır (Demirelli, 2003, 168; Süzen, 2004, 74; Saban, 2009, 167). Modellemeye dayalı öğretim ile yapılandırmacı yaklaşım arasında anlama düzeyleri bakımından fark olmaması her iki öğretim yönteminin de öğren- 
cilerin anlama düzeylerini eşit oranda etkilemiş olmasıyla ilişkili olabilir.

Deney ve kontrol grubu öğrencilerinin TYT ön puanları sabit tutulduğunda, MDFÖ ile öğrencilerin TYT son puanları arasında anlamlı bir ilişki bulunmuştur. HBAMD ile gerçekleştirilen öğrenme sürecinde öğretmenin, rol modeli olarak görev almasının yanı sıra, döngünün doğası gereği öğrencilerin problemi sürekli olarak sorgulamalarını sağlaması, fikir üretebilmeleri için yeterli süre tanıması ve her aşamada öğrencileri yüreklendirmesinin öğrencilerin yaratıc1lık düzeylerini olumlu yönde etkilediği söylenebilir (Sternberg, \& Williams, 1996, 13-16; Halloun, 2004, 193-215). HBAMD öğrencilerin öğretim ortamlarını kendi otonomilerini ve kendine güvenlerini destekleyecek şekilde organize etmektedir. Bireylerin, özerkliklerini ve kendine güvenlerini pekiştiren çevreler bireylerin yaratıcılıklarını geliştirme olasılığını arttırır (Öncü, 1992, 262).Yaratıcı düşünce bünyesinde problem çözme, muhakeme etme ve kavramlar arasında transferde bulunmak gibi MDFÖ etkinliklerinde yer alan birçok faktörü de barındırmaktadır (Erdener, 2013, 5). Ayrıca öğretim ortamlarında uygun biçimlerde kullanılan modellerin öğrencilerin hayal güçlerini ve yaratıcılıklarını geliştirmesi, MDFÖ ile öğrencilerin yaratıc1lıkları arasında anlamlı bir ilişki olduğu sonucunu desteklemektedir (Gödek, 2004, 58).

Uygulama sonrasında deney ve kontrol grubu öğrencilerinin ADT puanları sabit tutuldugunda, MDFÖ ile bir ay sonra uygulanan ADT puanları arasında anlamlı bir ilişki bulunmamıştır. Öğrencilerin gerçekleştirmiş oldukları tekrar sayıları bilginin unutulma hızını yavaşlattığı gibi öğrencilerde kalıcı öğrenmenin gerçekleşmesini sağlamaktadır (Arı, 2010, 288-291). HBAMD'deki süreçte öğrencilerin sahip oldukları ve yeni öğrendikleri bilgileri sıklıkla tekrar etmelerini sağlamaktadır (Halloun, 2004, 193-215). Ayrıca literatürde gerçekleştirilen araştırmalar incelendiğinde, MDFÖ'nün öğrencilerin kalıcı öğrenmeler gerçekleştirmelerine olumlu yönde etki ettiğine dair bir çalışmaya rastlamak mümkündür (Gobert, \& Pallant, 2004, 15). Bu bilgilerden yola çıkarak MDFÖ ile öğrencilerin hatırda tutma düzeyleri arasında anlamlı bir ilişki olması beklenmektedir. Buna karşın, araştırma sonucunda MDFÖ ile öğrencilerin hatırda tutuma düzeyleri arasında anlamlı bir ilişki bulunamamıştır. 5E modeli ile ilgili literatürdeki çalışmalar incelendiğinde 5E modelinin öğrencilerin hatırda tutuma düzeyini olumlu yönde etkilediğini gösteren çalışmaya rastlanmaktadır (Yalçın-A ğgül, \& Bayrakçeken, 2010, 525-526). MDFÖ ile yapılandırmacı yaklaşım arasında hatırda tutma düzeyleri bakımından fark olmaması her iki öğretim yönteminin de öğrencilerin anlama düzeylerini eşit oranda etkilemiş olması olabilir.

Dördüncü problem kapsamında öğrencilerle gerçekleştirilen görüşmeler sonucunda elde edilen bulgular incelendiğinde MDFÖ öğrencilerin zihinsel modellerini olumlu yönde geliştirdiği gözlenmiştir. MDFÖ temeli öğrencilerin sahip oldukları zihinsel modelleri geçerli olan bilimsel modellere doğru geliştirmektir. Bu nedenle MDFÖ'de gerçekleştirilen etkinlikler de hedef öğrencilerin zihinsel modellerini ortaya çıkarırken, uygun bir şekilde bu zihinsel modelleri geliştirmektir (Harrison, \& Treagust, 1998, 421). Ayrıca literatürdeki araştırmalar incelendiğinde, MDFÖ’nün öğrencilerin zihinsel modellerini olumlu yönde etkilediğine dair çalışmalar bulunmaktadır (Clement, \& Steinberg, 2002, 390; Ogan-Bekiroğlu, 2007, 580-581; Kurnaz, 2011). MDFÖ’nün doğası ve gerçekleştirilen çalışmalardan elde edilen sonuçlar, araştırmanın nitel boyutundaki gözlemleri destekler yöndedir.

\section{Sonuç}

Sonuç olarak, anlama ve hatırda tutma düzeyi açısından gruplar arasında fark bulunmadığı, yaratıcılık düzeylerinin ise deney grubu lehine olduğu ve araştırmanın nitel boyutunda ise MDÖY'nin öğrencilerin zihinsel modellerini olumlu yönde etkilediği gözlenmiştir. 


\section{Öneriler}

Fen ve Teknoloji Öğretmenlerinin Modellemeye Dayalı Öğretim Yöntemini uygularken; Öğretim sürecinin keşfetme basamağında öğretmenlerin etkinlikleri sınırlı sayıda (2 ya da 3 etkinlik) tutmalarının konunun dağılmasını ve öğrencilerin sıkılmasını engelleyeceği; öğretme sürecinin keşfetme basamağında kavram karikatürlerinin kullanılmasının öğrencilerin fikirlerini daha açık bir biçimde öne sürebilmesini sağlayacağı; sınıfla oluşturulacak modellerden önce modelle ilgili beyin firtınası tekniğinin uygulanmasının, ortaya daha yaratıcı modeller çıkaracağı ve sınıfla oluşturulan modellerin ders kitabındaki modellerle karşılaştırılmasının üst biliş becerilerini geliştireceği düşünülmektir.

\section{KAYNAKÇA}

Akın, F. M., \& Pesen, C. (2010). "Özdeşliklerin Elde Edilmesinde Tam Küp Modelinin Öğrenme Ürünlerine Etkileri”. Dicle Üniversitesi Ziya Gökalp Eğitim Fakültesi Dergisi, 14, 86-102.

Altunışık, R., Coşkun, R., Bayraktaroğlu, S., \& Yıldırım, E. (2010). Sosyal Bilimlerde Araştırma Yöntemleri (Spss Uygulamall). Sakarya: Sakarya Kitapevi.

Anderson, L. W., Krathwohl, D. R., Airasian, P. W., Cruikshank, K. A., Mayer, R. E., Pintrich, P. R., Raths, J., \& Wittrock, M. C. (2010). Öğrenme Öğretim ve Değerlendirme ile Ilgili Bir Sinfflama. A Taxonomy for Learning, Teaching and Assessing. Çev.: D. A. Özçelik. Ankara: Pegem Akademi.

Aslan, E. (2001). “Torrance Yaratıc1lık Düşünce Testi'nin Türkçe Versiyonu”. Marmara Üniversitesi Atatürk Ĕgitim Fakültesi Ĕgitim Bilimleri Dergisi, 14, 19-40.

Barab , S. A., Hay, K. E., Barnnet, M., \& Keating, T. (2000). "Virtual Solar System Project: Building Understanding Through Model Building”. Journal of Research in Science Teaching, 37/7, 719-756.

Büyüköztürk, Ş. (2010). Sosyal Bilimler İçin Veri Analizi El Kitabı. Ankara: Pegem A Akademi.

Büyüköztürk, Ş., Kılıç Çakmak, E., Akgün, Ö. E., Karadeniz, Ş., \& Demirel, F. (2012). Bilimsel Araştırma Yöntemleri. Ankara: Pegem Akademi.

Clement, J. J., \& Steinberg, M. S. (2002). "Step-Wise Evolution of Mental Models of Electric Circuits: " A Learning- Aloude" Case Study”. The Journal of the Learning Science, 11/4, 389-452.

Demirelli, H. (2003). "Yapılandırıcı Öğrenme Teorisine Dayalı Bir Labaratuvar Aktivitesi: Elektrot Kalibrasyonu ve Gran Metodu”. Gazi Üniversitesi Gazi Eğitim Fakültesi Dergisi, 23/2, 161-170.

Durmuş, S., \& Kocakülah, M. S. (2006). "Fen ve Matematik Öğretiminde Modelleme”. Fen ve Teknoloji Öğretimi, 299-317. Ankara: Pegem A Yayıncılık.

Erdener, N. "Eğitimde Yaratıcı Düşünme- Tasarım ve Öngörü Yeteneğinin Geliştirilmesi”. Erişim tarihi: 10.04.2013. Http://www.egitim.aku.edu.tr/kho2.doc.

Frederiksen, J. R., White, B. Y., \& Gutwill, J. (1998). "Dynamic Mental Models in Learning Science: The Importance of Constructing Derivational Linkages Among Models”. Journal of Research in Science Teaching, 36/7, 806-836.

Gobert, J. D., \& Buckley, B. C. (2000). "Introduction to Model-Based Teaching and Learning in Science Education”. International Journal of Science Education, 2/9, 891-894.

Gobert, J. D., \& Pallant, A. (2004). "Fostering Students' Epistemologies of Models Via Authentic ModelBased Tasks". Journal of Science Education and Technology, 13/1, 7-22.

Gödek, Y. (2004). "The Importance of Modelling in Science Education and in Teacher Education". Journal of Hacettepe Universty Education Faculty, 26, 54-61.

Güneş, B., Gülçiçek, Ç., \& Bağcı, N. (2004). "Eğitim Fakültesindeki Fen ve Matematik Öğretim Elemanlarının Model ve Modellemeler Hakkındaki Görüşlerinin İncelenmesi”. Türk Fen Eğitim Dergisi, 1/1, 35-48.

Halloun, İ. A. (2004). Modelling Theory in Science Education. Netherlands: Springer.

Harrison, A. G., \& Treagust, D. F. (1998). "Modelling in Science Lessons: Are There Better Ways to Learn With Models?”. School Science and Mathematics, 98/8, 420-429. 
Köseoğlu, F. "Fen Eğitiminde Bilimin Doğası ve Öğretimi”. TÜBİTAK BGDEB 2229, Kimya-I Çalıştayı (3 Kasım, 2010). Çanakkale, Türkiye.

Kurnaz, M. A. (2011). Enerji Konusunda Model Tabanlı Öğrenme Yaklaşımına Göre Tasarlanan Öğrenme Ortamlarının Zihinsel Model Gelişimine Etkisi. Yayınlanmamış Doktara Tezi. Karadeniz Teknik Üniversitesi Eğitim Bilimleri Enstitüsü, Trabzon.

Ogan-Bekiroğlu, F. (2007). "Effects o Model-Based Teaching on Pre-Service Physics Teachers' Conceptions of the Moon, Moon Phases, and Other Lunar Phenomena”. International Journal of Science Education, 29/5, 555-593.

Öncü, T. (1992). "Yaratıcıllğın Betimlenmesi ve Yaratıcılık Üzerine Çevresel Etkiler". Ankara Üniversitesi Dil ve Tarih-Coğrafya Fakültesi Felsefe Bölümü Dergisi, 4, 29-38.

Saban, A. (2009). Öğrenme Öğretme Süreci Yeni Teori ve Yaklaşımlar. Ankara: Nobel Yayın Dağıtım.

Sternberg, R. J., \& Williams, W. M. (1996). How to Develop Student Creativity. Virginia: Alexandria.

Süzen, S. (2004). Yedinci Sinıf Fen Bilgisi Dersinde Fiziksel ve Kimyasal Değişmeler Konusunda Öğrencilerin Bilişsel Alanın Bilgi ve Kavrama Düzeyleri ve Tutumları Üzerine Yapılandırmacı Öğrenme Modelinin Üzerine Etkisi. Yayınlanmış Yüksek Lisans Tezi. Gazi Üniversitesi Eğitim Bilimleri Enstitüsü, Ankara.

Tekin, H. (1993). Eğitimde Ölçme Değerlendirme. Ankara: Yargı Yayınları.

Torrance , E. P. (1974). Torrance Tests of Creative Thinking Directions Manual and Scording Guide, Verbal Test Booklet A and B. Princeten: Scholastic Testing Service.

Torrance, E. P. (1966). Torrance Tests of Creative Thinking Norms-Technical Manual Research Edition . USA: Personel Pres.

Turgut, F. M., \& Baykul, Y. (2012). Eğitimde Ölçme Değerlendirme Metotları. Ankara: Pegem Akademi.

Ünal Çoban, G. (2009). Modellemeye Dayalı Fen Öğretiminin Öğrencilerin Kavramsal Anlama Düzeylerine, Bilimsel Süreç Becerilerine, Bilimsel Bilgi ve Varlık Anlaylşlarına Etkisi: 7. Sinıf Işılk Ünitesi Örneği. Yayınlanmış Doktara Tezi. Dokuz Eylül Üniversitesi Eğitim Bilimleri Enstitüsü, İzmir.

Vosniadou, S. (1994). "Capturing and Modelling the Process of Conseptual Change”. Learning and Intruction, 4, 45-69.

Yalçın-Ağgül, F., \& Bayrakçeken, S. (2010). "The Efect of 5E Learning Model on Pre-Service Science Teachers' Achievement of Acids-Bases Subject”. International Online Journal of Educational Sciences, 2, 508-531.

Yıldırım, A., \& Şimşek, H. (2011). Sosyal Bilimlerde Araştırma Yöntemleri. Ankara: Seçkin. 